\title{
The Americanization of Danish Journalism
}

\author{
Anders Bo Rasmussen
}

\begin{abstract}
This article provides two examples of the Americanization of Danish journalism through an examination of Danish journalists' adaptation of New Journalism and investigative journalism as seen through the pages of the Danish Union of Journalists' periodical Journalisten. The article answers Daniel Hallin and Paolo Mancini's call for more "concrete" studies of the Americanization process. The study demonstrates how news media in the United States, in the two examples provided, have served as an important source of methodological inspiration for Danish journalists from the late 1960s forward.
\end{abstract}

Keywords: Americanization, transnationalization, journalism practice, New Journalism, investigative journalism, journalism education.

\section{Introduction}

At least since the early $20^{\text {th }}$ century, complaints about the American newspaper industry have found their way into Danish journalistic publications due to a fear of American influence on local journalistic practices. Consciously or unconsciously, these laments have been used by Danish journalists to disparage the commercially-motivated American propensity to focus on the "shocking and astonishing" as opposed to the more "serious" journalism advocated by Danish critics. ${ }^{1}$ Yet certain aspects of American journalism, i.e. the use of interviews or the ideal of objectivity, have also served as inspiration for Scandinavian journalists. More recently American journalistic innovations such as New Journalism and investigative journalism have also been adopted and adapted by Scandinavian reporters. New Journalism, according to a book by that name published in 1973 by Tom Wolfe, was a novel approach to journalism in the United States inspired by literary devices and emphasizing telling stories through setting scenes, recording complete dialogues, following the point-of-view of a particular character and describing everyday details throughout the story. ${ }^{2}$

Investigative journalism, on the other hand, based on the book "All the President's Men" from 1974 by Bob Woodward and Carl Bernstein, was characterized by extensive research, fact-checking, all-encompassing interviews, taped conversations and analysis of written documents including financial records, correspondences and court records. ${ }^{3}$

This paper argues that Wolfe's New Journalism and the Watergate-based investigative journalism in turn inspired pioneering Danish reporters. Exploring how this process of Americanization happened from the ground up is the focus of the subsequent pages. By 
reading American journalists' work, going on transnational educational exchanges and writing about new insights, Danish journalists over a decade adopted and adapted New Journalism and investigative journalism into their educational institutions and professional practice. This overall development of Americanization has been noted by media scholars Daniel Hallin and Paolo Mancini as well,

Not only have European media and communication processes come to resemble American patterns in important ways, but there is clear evidence of direct American influence, starting at least from the late nineteenth century, when American forms of journalism were widely imitated. ${ }^{4}$

Within the past decade several comparative studies of Scandinavian and American news content have been conducted testing theories about national differences in news coverage. Underlying these studies is an assumption, often based on Hallin and Mancini's Comparing Media Systems, that Scandinavian news content is increasingly converging towards the more commercially-oriented media model that has developed in the United States.

Pierre Bourdieu's field theory, which emphasizes structural factors such as commercial influence on media content, has been put to an empirical test through analysis of large samples of newspaper articles or synthesis of existing research. Yet despite Hallin and Mancini's argument that the American liberal model has "clearly become increasingly dominant across Europe as well as North America," the results are mixed. In their 2006 study of election coverage, Jesper Strömbäck and Daniela Dimitrova conclude that American newspapers treat politics as a political game more frequently than Swedish newspapers do, thereby supporting the idea that there are still important differences between Scandinavian and American news coverage. ${ }^{5}$

Hallin and Rodney Benson have argued that the American government's lack of regulation and subsidies to media organizations is one of the main differences between American and European media models. To be sure, access to routine national government subsidies is one obvious area in which Scandinavian press institutions remain separate from their American counterparts, and which might suggest that the adoption of other attributes of the American liberal model is not absolute.

Hence, Sigurd Allern and Mark Blach-Ørsten, in a study from 2011, concluded that Anglo-American commercialization has not "simply morphed the democratic corporatist model into the liberal model." ${ }^{\circ}$ Other quantitative studies of Scandinavian and American news coverage have likewise thus far not found a clear tendency of increased homogenization between the United States and Scandinavia. ${ }^{7}$

According to Hallin and Benson, fewer direct economic ties between politicians and journalists can lead to a media environment conducive to increased investigative journalism, because journalists will not be worried about biting the hand that feeds them. However, mounting commercial pressure is also argued to decrease time-consuming investigative journalism while leading to increased emphasis on opinion polls, interpretation and opinion in news coverage at the expense of political neutrality and balanced reporting. ${ }^{8}$

While the aforementioned structural and quantitative studies of Americanization have nuanced our understanding of American influence on Scandinavian journalism, they are, as Hallin and Mancini remind us, only "useful to a point." What really matters is "how journalists or other media personnel function in practice." In other words, 
according to Hallin and Mancini, there has been a lack of "concrete" bottom-up studies on Americanization that focus, for instance, on examining journalism education, transnational interaction between journalists, the use of foreign consultants, as well as the content of media seminars.

Consequently, the present paper addresses the call for more tangible studies of Americanization by conducting two studies - of New Journalism and investigative journalism - where the Americanization process can be followed through the work of key journalists in the pages of the Danish Union of Journalists' periodical Journalisten.

\section{Theories of Americanization}

In his study Americanism and Americanization: A Critical History of Domestic and Global Influence, Dutch sociologist Mel van Elteren defines Americanization broadly as processes emanating from America that impact the norms or behaviors of nonAmericans. ${ }^{10}$

Van Elteren theoretically grounds his study in a hybrid position between the concept of cultural imperialism - meaning American influence that the receiving country has no ability to resist - and what he terms "extreme social constructionism" - an approach in which the very existence of a "real" America is called into question. ${ }^{11}$ Van Elteren understands Americanization as a middle ground where receiving nations' agency is taken into account, but also recognizes that America is a "stubborn, historical-societal reality," with tangible political and cultural influence on other nations. Building on Van Elteren's definition of Americanization, Danish historian Nils Arne Sørensen has pointed out that actors in the Americanization process must be sought on both sides of the Atlantic, but emphasizes that Americanization and Europeanization do not hold equal weight. On the contrary, the relationship between the United States and Scandinavia is to be understood as an asymmetric power relation in which the United States, more often than not, sets the agenda. In other words, Americanization is understood here as a process that has the power to modify the behavior of non-Americans - in this case Danish media institutions and journalists. ${ }^{12}$

\section{Method}

The period of the late 1960s and early 1970s serves as a useful starting point for a study of Americanization, as the first Danish School of Journalism was formally established in 1971 and thereby helped change the way journalism was studied and practiced in Denmark. ${ }^{13}$ Simultaneously, in terms of research, reporting and education, Danish journalists debated perceived positive and negative influences from the United States, where increased professionalism - meaning a renewed commitment to public service, an ideal of objectivity and the rejection of political pressure - was beginning to show, as these developments were presented in the Danish Union of Journalists' periodical Journalisten. ${ }^{14}$

Hence, the current study is delimited primarily to Journalisten, a publication received - and contributed to - by an estimated 90-95 percent of Danish journalists, which has allowed for a close reading of all articles related to the United States and Scandinavia from 1968 and forward. ${ }^{15}$ An initial reading of every Journalisten edition between 1968 
and 1990 yielded a sample of 348 articles dealing with international aspects connected to Scandinavian journalism. A final sample of 58 articles, dealing specifically with methodology and the flow of information from the United States, was selected for a detailed analysis while the rest were used in the study for context.

In 2006, Van Elteren proposed a framework for historical analysis of Americanization that has subsequently been widely used by researchers. Van Elteren's framework consists of the analytical categories "transmission," "transnationalization," and "appropriation" and distinguishes between structural Americanization - military, technological and economic influence - and symbolic Americanization - American influence in the cultural realm.

The analysis is carried out on three levels: "basic characteristics" of influence coming from the United States, America's position in the global system, and "relevant sectors in the United States." The current article focuses on the latter, specifically the sector of journalism, with the aim of locating what Van Elteren terms "key individuals" - here focused on journalists who participated in the transnational knowledge transfer between the United States and Scandinavia - in the analytically defined three-step process of Americanization seen here below in Table $1 .{ }^{16}$

Table 1. Van Elteren's framework for Americanization: Transmission from the United States, picked up through transnational knowledge exchange and appropriated by the receiving country

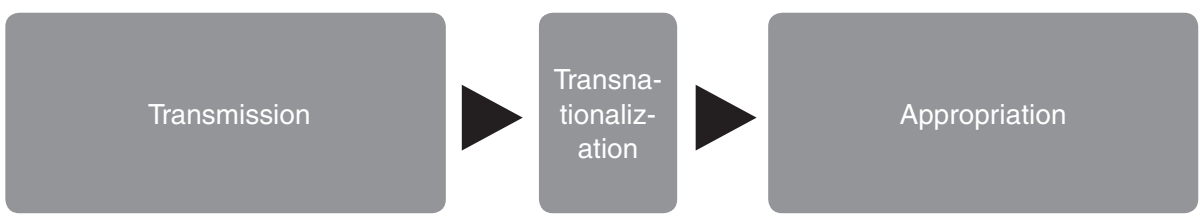

Van Elteren understands transmission broadly, as processes originating in the United States that are then transferred to other countries, i.e. the invention of the Internet, new technology or cultural diffusion. The Swedish managing director of Dagens Nyheter, Carl-Adam Nycop, for example, had first-hand experience of American transmission of data technology in 1969, knowledge that was deemed so relevant to Danish media corporations that he was invited to lecture on the topic in Denmark. Gaining inspiration from the United States through a transnational intermediary like Nycop is a phenomenon Van Elteren describes as "secondary appropriation." For example, in the realm of technology, but also methodology, Swedish and Norwegian journalists have at times served as important reference points, and collaborators, for Danish media employees when it comes to American influence. ${ }^{17}$

The mode of transfer in Van Elteren's model is transnationalization, a process occurring in "contact zones," meaning areas where "local meanings and practices interact with the intruding beliefs and practices." 18 These contact zones are visible through educational exchange by journalism teachers or journalists themselves and often perpetuated when the exchanged individuals return home.

Appropriation in Van Elteren's framework means identifying the "volume ('size' and scale) of ideas, goods, services and practices imported or adopted from the United 
States, and the extent of their reach." 19 The articles in Journalisten reflect national and international trends and are viewed here as a good indicator of initial appropriation, as journalistic trends arguably would not be published in the Danish Union of Journalists' periodical if they were not deemed relevant for a broad media readership. ${ }^{20}$

\section{A New Journalism}

On an educational exchange in 1969, Kurt Boelsgaard, future political editor of Børsen (Denmark's answer to the Wall Street Journal), found American journalists to be much more sophisticated than their Danish counterparts. The United States, he claimed, was precisely where one should go for a cutting-edge journalistic education. ${ }^{21}$ In the ensuing years, the journalism methods taught in the United States, especially New Journalism and investigative reporting, were disseminated in Danish educational institutions through texts, teacher exchange and journalists' own visits to American media organizations. The subsequent sections follow the process of transmission, transnationalization and appropriation, as they become apparent in Journalisten. ${ }^{22}$

\section{Transmission and Transnationalization}

Articles in Journalisten in the early 1970s show that New Journalism was being introduced to a Danish audience by a small, elite group of journalists who all had ties to the United States. The American experimental journalist Tom Wolfe had his work The Kandy-Kolored Tangerine-Flake Streamline Baby \& The Pump House Gang translated into Danish in 1970 by Mogens Berendt, who worked for the prestigious weekly Weekendavisen. In subsequent years Berendt, who a few years earlier had finished part of his journalism training at Time Magazine and The New York Times, along with a handful of other Danish journalists, played an important role in introducing Danish reporters to New Journalism, while implementing the methods in his own writing. ${ }^{23}$

Yet for the more general Danish journalistic audience, Tom Wolfe's book on The New Journalism published in 1973 offered the first coherent description of this novel field while simultaneously serving as an important arbiter of its transmission. ${ }^{24}$

Consequently, when Berendt in 1974 used Wolfe's book to introduce New Journalism to all the members of the Danish Journalist's Union through an article in Journalisten, he served as an important transnational link between Danish and American journalism. In the pages of Journalisten, Berendt was the first point of contact between Tom Wolfe's transmission and a more general appropriation of New Journalism in Denmark in the 1970's. ${ }^{25}$

In his article, Berendt described the development of New Journalism and ended with a discussion of whether or not New Journalism actually was new. Berendt came to the conclusion that in the United States New Journalism was new because the genre of hard news, based on the inverted news triangle, had dominated newsrooms since the 1920s. Yet in Europe, Berendt argued there had historically been different traditions that made New Journalism less novel than it was in the United States.

French journalism, for instance, has a quite different tradition, and our own Danish tradition luckily never quite let the old behemoths' penchant for lyrical journalism slip away. Unfortunately we probably have more of the old, new journalists, than of the all new - we too have tried to become Anglo-Saxon in our feature after all. ${ }^{26}$ 
To Berendt what was new about New Journalism was the literary approach to journalism. Before New Journalism was introduced in Denmark, novelists primarily wrote literature while journalists primarily wrote descriptive, fact-based, when, where, why, journalism. Yet American writers like Gay Talese and Tom Wolfe had more recently successfully blended the genres and inspired journalists outside U.S. borders. ${ }^{27}$

By way of his introductory article in Journalisten Berendt, along with a handful of contemporary colleagues, who personally also had spent time in "contact zones" with American journalism, served as a necessary transnational conduit for adaptation of New Journalism through dissemination of methodological knowledge between the United States and Denmark, but they did not do so uncritically. ${ }^{28}$

Some Danish journalists asserted that they were inspired by Danish literature before they ever heard of New Journalism, while Danish media historian John Chr. Jørgensen on the other hand contends that "one sees many examples of New Journalism" in these critical journalists' work. ${ }^{29}$

The fact that Berendt analyzed the merits as well as less novel aspects of New Journalism is a testament to the fact that Danish journalists consciously adopted and adapted American methodologies - they were not forced upon them. Berendt's approach to New Journalism thereby serves as a concrete example of Van Elteren's theoretical understanding of Americanization, which rejects cultural imperialism but acknowledges the attraction and power of processes emanating from America.

Jørgensen argues that New Journalism to this day inspires Danish journalists and that the Danes are in a state of dependence in regard to American writers. However, instead of wholeheartedly adopting New Journalism, the Danish writers have adapted the approach to fit their own needs. ${ }^{30}$

\section{Appropriation}

Based on Van Elteren's framework, an important shift toward the appropriation of New Journalism in Denmark occurred in 1979 when Danish journalists negotiated with their employers for the right to further educate themselves one week every year.

Starting in 1980 The Journalistic Continuing Education (DJE) offered journalism courses partly inspired by trends outside Danish borders, as was noted in the first course catalog.

Both Europe and the United States are experimenting these years with the principles behind reporting, reportage and feature-articles. A final answer has probably not been found but during a stay at The Graduate School of Journalism, Columbia University, New York, Gert Smistrup has looked at both the newest tendencies within [article] construction and the newest development within 'New Journalism'. ${ }^{31}$

For the first time, Danish journalists who had not been directly inspired by transmission of New Journalism, personified by Wolfe and Talese, or touched by personal interaction with Danish journalists like Berendt, who had transnational journalistic experience, could now take classes and themselves incorporate New Journalism into their professional practices without going to the United States.

Another expression of Danish journalists' appropriation of New Journalism was described in the pages of Journalisten in 1983. During this year, the first book in Dan- 
ish about New Journalism was published..$^{32}$ Journalisten printed a review of the book and in subsequent years more references to New Journalism appeared in the journalists' periodical. ${ }^{33}$ In 1984, the Danish Gonzo Publishing house, named after Hunter S. Thompson's self-proclaimed style of New Journalism, was established and put out a book called Reporter på afveje (Reporter Astray), which was a compilation of 13 young journalists' experimentation with New Journalism. Additionally, by 1984 a course called "The Art of Telling a Good Journalistic Story" was introduced at the Danish School of Journalism. The course utilized many of the literary tropes of New Journalism and for the first time incorporated into a Danish curriculum the journalistic trailblazing that had occurred in the United States in the 1960s. ${ }^{34}$ Consequently, by 1984 literary approaches to journalism writing reached a broader audience and were so well-known that Berendt that year declared New Journalism "dead."

There is no longer a need for New Journalism as an independent form. Like fertilizer that is slowly integrated into the biological system, the elements of New Journalism have slipped into mainstream journalism. ${ }^{35}$

Judging from the pages of Journalisten, New Journalism had by 1984 been appropriated and incorporated into the Danish journalistic mainstream. In the late 1960s, access to learning about New Journalism had first been "restricted" to those Danish journalists who had been in the United States or knew someone from whom they could learn. In 1980, DJE introduced courses in which New Journalism was part of a bigger whole, but these courses had limited availability. The introduction of a Danish-language book in 1983 was therefore an important final step in making New Journalism available to all Danes, as it was, according to Jørgensen, modeled on Wolfe's description of New Journalism. $^{36}$

\section{The Watergate Legacy}

When The Washington Post from 1972 to 1974 helped reveal the Watergate scandal, which eventually resulted in President Richard Nixon's resignation, the newspaper also sparked an interest in investigative reporting that stretched far beyond American borders. According to British journalist John Pilger, the Washington Post's Watergate coverage helped solidify the parameters of a new journalistic concept.

The term, investigative journalism, did not exist when I began my career; it became fashionable in the 1960's and 1970's and especially when Bob Woodward and Carl Bernstein exposed the Watergate scandal. ${ }^{37}$

Yet by 1978 Danish journalists writing in Journalisten still did not know how to describe Woodward and Bernstein's approach to journalism, as evidenced by Kurt Søndergaard's attempted explanation: "investigative reporting. ${ }^{38}$

Although investigative journalism had not become mainstream in Denmark by 1978, in the subsequent decade, it became part of Danish journalists' repertoire and has since played an increasingly important role in their professional identity. 


\section{Transmission and Transnationalization}

Danish journalists who got their inspiration from Journalisten first heard about "investigative reporting" in October of 1974 when an enthusiastic review of Woodward and Bernstein's All The President's Men, based on a Norwegian translation, was printed in the periodical.

The advanced journalistic cookbooks for the Danish market are few and far between (...) 'All the President's Men' is available in Norwegian for 62 kroner, and it is much more than an exciting crime story about the ripples on the surface of the puddle of mud which was called the Nixon Administration. It is a brilliant introduction to a journalistic genre that English and American journalists have practiced and cultivated in recent years, investigative reporting. ${ }^{39}$

To the reviewer Ole Schierbeck, All The President's Men describing Woodward and Bernstein's journalistic experience during Watergate was as exciting as anything a journalist could get his or her hands on. The British Sunday Times was mentioned as a forerunner in investigative reporting along with the American magazine Newsday. At Columbia University, the Graduate School of Journalism had begun offering classes in investigative journalism, "and now we have a document in Denmark which is well-written and meticulously depicts how one goes about toppling a president." 40 Any references to Danish counterparts were lacking in Schierbeck's review, thereby indicating that investigative reporting was not yet associated with any Danish news or educational institution.

Schierbeck enthusiastically described the methods behind investigative reporting as "protracted research" that left no stone unturned, no statement unchecked and accounted for the detail-oriented approach utilized by Woodward and Bernstein. With an eye to the differences in scale between Denmark and the United States, Schierbeck did not end his review with pointing out the book's potential for toppling presidents and prime ministers. Schierbeck ended instead on a slightly less ambitious suggestion, "Read it before your [own] mayor" and thereby again underlined the fact that Danish journalists adapted techniques from the United States instead of uncritically adopting them. ${ }^{41}$

Despite Schierbeck's positive review of All The President's Men, and the methodology behind it, during the 1970s only a few Danish newspapers picked up on the possibilities of investigative journalism. When Journalisten broached the topic again in 1978 it was to describe a guest lecture by two Americans. The Pulitzer Prize-winning investigative journalist Clark Mollenhoff visited the Danish School of Journalism to talk about investigative reporting together with Professor Melvin Mencher. Mollenhoff and Mencher's lecture spurred an article in Journalisten giving precepts for conducting investigative reporting. ${ }^{42}$

In the same issue, an article in Journalisten depicted a case in which an American journalist had been killed, and the association of Investigative Reporters and Editors Inc. decided to get to the bottom of the crime. ${ }^{43}$

At least two things are notable about this May issue of Journalisten from 1978. First, the articles show that the Danish School of Journalism, four years after the Columbia School of Journalism, started to show an interest in investigative reporting, and therefore brought in American teachers to introduce the students to this journalistic approach. The Danish School of Journalism, the only Danish journalistic educational institution 
at that time, thereby established a transnational link to the United States in regard to investigative journalism.

Second, the articles also reveal that investigative reporting in the United States since 1975 had been organized around the tenets of Investigative Reporters and Editors Inc. This organization demonstrated a certain cohesiveness in its investigative journalism approach, just as Tom Wolfe's book prescribed the methodology of New Journalism. Investigative reporters in the United States thus had procedures and routines - such as in-depth scrutiny of public records, and extensive interviews, over a lengthy period of time to uncover abuse of power - which tied them together and separated them from other approaches to journalism.

Consequently, the transmission of investigative journalism from the United States had begun, and the transnationalization exemplified by the two American investigative journalism guest lecturers at the Danish School of Journalism also indicated that interest in investigative journalism was taking shape within the field of education. ${ }^{44}$ Despite the interest detectable in investigative journalism at the educational level, there was no formal Danish association of investigative reporters like the one established in the United States in 1978. Yet in the following years, articles on investigative journalism regularly found their way into the pages of Journalisten.

\section{Appropriation}

Between February and April 1982, Journalisten again brought attention to the theme of investigative journalism when articles were published about the lack of in-depth journalism in Scandinavia in three successive editions. Yet the article series concluded that the great emphasis on day-to-day news undermined the potential for investigative journalism in most newspapers. ${ }^{45}$

In June of 1982, Journalisten ran a story about the first Danish book on "research journalism," which the authors, Kim Minke and Mogens Meilby, deemed "the most professional journalistic form" supported by the fact that half of the Cavling Prizes, the Danish equivalent of the American Pulitzer Prize, were awarded to journalists who took a research approach to their profession.

Meilby and Minke both taught at the Danish School of Journalism and based their book on interviews with 23 Danish journalists while using American, Norwegian and Swedish secondary literature. The interviewed journalists, among them Ole Schierbeck, who had been part of the American Press Institute exchange at Columbia University in 1972, practiced research journalism or investigative reporting "from time to time." 46 The book's tenets, which were inspired by investigative journalism in the United States, would be used to teach a class at the Danish School of Journalism starting by 1983, the same year the book was published.

During the preparation for this project we have studied what has been written in other countries about the topic and have found that the United States - especially after Watergate - has attained a quite rich literature about 'investigative reporting,' which to a large extent corresponds to what many Danish journalists seem to understand by 'in-depth journalism'. ${ }^{47}$

As Meilby and Minke's quote indicates, in the case of investigative journalism the United States was once again seen as a pioneer country in terms of innovation. The 
transnational influence referred to by the authors is apparent in the book's bibliography as well. Out of 27 literature references, 15 are Anglo-American with Woodward and Bernstein's book from 1974 being the earliest reference to investigative journalism. The six Scandinavian, meaning Swedish and Norwegian, references to the same topic were published between 1977 and $1981 .{ }^{48}$

Consequently, Meilby and Minke's book from 1983 is the first example of research journalism's appropriation in Denmark. Meilby and Minke's publication was followed by a more definitive organizational embrace of American-inspired investigative journalism six years later.

Early in 1990, Journalisten published three articles about the establishment of the Danish Association for Investigative Journalism during a seminar in December 1989 and informed readers that,

The Association aims to further investigative, in-depth and critical journalism and will work for better education in investigative journalism. (...) Over two days, the seminar introduced a host of Danish and foreign guests, who related their personal experiences and visions for investigative journalism. On Friday the Pulitzer Prize winner Ric Tulsky, executive director of the American Investigative Reporters and Editors, for one was on the podium. The American association inspired the creation of a Swedish association of investigative journalism that spurred the idea of a Danish counterpart. ${ }^{49}$

Throughout the process of appropriation, however, an undercurrent of "secondary appropriation" was also apparent. Schierbeck reviewed a Norwegian edition of All The President's Men, Meilby and Minke's book was partly based on Swedish and Norwegian literature, and the the Danish Association for Investigative Journalism was established in the wake of a Swedish counterpart. Clearly, Danish journalists looked to developments in the most immediate neighboring countries, as well as the United States, which supports the theory that American journalistic methods were not purely and uncritically adopted, but adapted to fit Scandinavian needs.

Asserting that investigative journalism in Denmark was inspired by the United States alone would therefore be going too far. In 1982, The Danish tabloid Ekstra Bladet was described as one of the few Danish media outlets that had successfully practiced investigative journalism in Denmark over the years and even published a variant of investigative journalism before anyone had heard of Watergate.

According to an internally-produced anniversary book from 2004, the newspaper launched a series of investigative articles uncovering fraud in the housing market in and around Copenhagen in 1963. In Ekstra Bladet's lore, the article series came to signify an important shift toward taking a stance on behalf of the little man against the injustice of society and "helped develop an investigative campaigning journalism'." 50

Yet critics pointed out that Ekstra Bladet's campaigning journalism at times spilled over to character assassination and that the newspaper's journalists also occasionally lacked documentation for the stories they ran. The newspaper's writers and management, according to a former employee, justified such practices simply as a "calculated risk." 51

As such, Ekstra Bladet's method was only partially seen as an example to follow. While the reporting was good enough to earn Ekstra Bladet a Cavling Prize, it did not reach the level of professionalism displayed by Woodward and Bernstein. Schierbeck in 
1974 did not even mention Ekstra Bladet's coverage and called the Watergate coverage "advanced," while underlining that All The President's Men was a brilliant introduction to the journalistic genre called investigative journalism.

However, in a different example of transnational inspiration, it is important to incorporate the influence of German journalist Günter Wallraff on Scandinavian investigative journalists. For example, Alex Frank Larsen, author of Reportere på afveje (Reporters Astray), who in 1986 won a Cavling Prize for his exposure of doctors' excessive use of $L S D$ on mental patients, stated that he was directly inspired by Wallraff's in-depth journalism the first time he went undercover in 1982. ${ }^{52}$ Additionally, the name Walraff is incorporated into the Scandinavian journalistic vocabulary as "Wallraffing," and has as such become synonymous with investigative journalism based on the method of going undercover to do research.

Yet the fact that Wallraff's primary journalistic method was (and continues to be) undercover journalism separates his approach to investigative journalism from Woodward and Bernstein and also separates it from an organization like Investigative Reporters and Editors Inc. ${ }^{53}$

Undercover reporting is just one of many tools in the investigative journalists' toolkit, which also incorporates all-encompassing interviews, requests for access to restricted documents, extensive research, fact-checking, taped conversations, and analysis of written documents such as financial and court records. Modeled on an American and subsequently Swedish counterpart, these different methodologies were all appropriated by Danish investigative journalists with the establishment of The Danish Association for Investigative Journalism in December 1989.

\section{Conclusion}

Heeding Hallin and Mancini's call for more concrete bottom-up studies of Americanization, the present article has found that Tom Wolfe's New Journalism and the Watergate-inspired investigative journalism between 1970 and 1990 were adapted into the mainstream of Danish journalistic practice.

At times this process took place through "secondary appropriation" from neighboring countries such as Sweden, Norway and Germany, but the primary source of inspiration came from the United States. To the readers and contributors of Journalisten in the 1970 s and 1980s, New Journalism and investigative journalism were at the forefront of journalistic development and subsequently adapted to fit local needs through a process of transmission over transnationalization to appropriation. The fact that American journalistic practices were adapted to fit Scandinavian reporting needs supports Van Elteren's argument that the Americanization process is more dynamic than the theory of cultural imperialism suggests. Additionally, the present findings lend support to the idea of Americanization as an asymmetric power relation in which the United States, more often than not, sets the agenda. Furthermore, the patterns of American influence discernible through the pages of Journalisten during the 1970s and 1980s seem visible even today.

Through courses at the Poynter Institute in Florida, Danish journalists in the 1990s increasingly appropriated the idea of journalistic coaching while, most recently, the Danish online media company Zetland was nominated for the Cavling Prize. Zetland 
was founded in 2012 by Danish journalists partially educated in the United States and inspired by American websites such as Byliner.com and Atavist.com.

Consequently, American media developments seem to be a consistent source of inspiration for Scandinavian journalists, and future studies - focusing on concrete journalistic output, transnational "contact zones," and different modes of appropriation - will therefore likely yield additional insight into how the process of Americanication concretely impacts journalistic practice in Scandinavia.

\section{Notes}

1. H. T. Peck, 'Amerikansk Journalistik [American Journalism]', Journalisten, October 1 (1906). Peck mentions the focus on sensation, celebrities and personalization coverage as something uniquely American "The lack of tact, sick vulgarity and shamelessness has never seen such a dreadful development as the one that the American press, even in its most excellent representatives, not only tolerates, but recommends." My translation.

2. Tom Wolfe, The New Journalism: With an Anthology Edited by Tom Wolfe and E. W. Johnson (London: Picador, 1996). Page 11-54.

3. Bob Woodward and Carl Bernstein, All the President's Men (Paperback edn.; New York: Pocket Books, 2005). Page 32-36 and 225-227 as well as 330-335.

4. Daniel C. Hallin and Paolo Mancini, Comparing Media Systems. Three Models of Media and Politics (Cambridge: Cambridge University Press, 2004). Page 254.

5. Jesper Strömbäck and Daniela V. Dimitrova, 'Political and Media Systems Matter: A Comparison of Election News Coverage in Sweden and the United States', Press/Politics, 11/4 (2006), 131-47.

6. Sigurd Allern and Mark Blach-Ørsten, 'The News Media as a Political Institution : A Scandinavian Perspective', Journalism Studies, 12/1 (2011), 92-105.

7. Hallin and Mancini, Comparing Media Systems. Three Models of Media and Politics. Page 200-201. See also Mel Van Elteren, Americanism and Americanization: A Critical History of Domestic and Global Influence (Jefferson, North Carolina: McFarland \& Company, Inc., Publishers, 2006a). Page 103 and 251-259.

8. Strömbäck and Dimitrova, 'Political and Media Systems Matter: A Comparison of Election News Coverage in Sweden and the United States', ( See also Daniel C. Hallin and Rodney Benson, 'How States, Markets and Globalization Shape the News: The French and Us National Press, 1965-97', European Journal of Communication, 22/1 (2007), 27-48. As well as Rodney Benson et al., 'Media Systems Online and Off: Comparing the Form of News in the United States, Denmark and France', Journal of Communication, 62/1 (2012), 21-38. Also James T. Hamilton, 'The Market and the Media', in Geneva Overholser and Kathleen Hall Jamieson (eds.), The Press (Institutions of American Democracy; New York: Oxford University Press, 2005). Page 356.

9. Hallin and Mancini, Comparing Media Systems. Three Models of Media and Politics. Page 303-304.

10. Mel Van Elteren, 'Rethinking Americanization Abroad: Toward a Critical Alternative to Prevailing Paradigms', The Journal of American Culture, 29/3 (2006b). Page 345.

11. Elteren, Americanism and Americanization: A Critical History of Domestic and Global Influence. Page 125-131.

12. Nils Arne Sørensen, 'Kulturmøder, Selvkolonisering Og Imperialisme Om Usamerikaniseringen Af Europa [Cultural Encounters, Self-Colonialization and Imperialism: About Usamericanization of Europe]', in Anne Magnussen Sissel Bjerrum Fossat, Klaus Petersen, Nils Arne Sørensen, (ed.), Transnationale Historier [Transnational Histories] (Odense: Syddansk Universitetsforlag, 2009). Page 190.

13. Wolfe, The New Journalism: With an Anthology Edited by Tom Wolfe and E. W. Johnson. Page 15.

14. Daniel C. Hallin, 'Commercialism and Professionalism in the American News Media', in James Curran and Michael Gurevitch (eds.), Mass Media and Society (3rd edn.; London: Oxford University Press, 2000). Page 220-233. See also David Halberstam, The Powers That Be (Urbana and Chicago: University of Illinois Press, 2000). Page 345.

15. Morten Skovsgaard and Arjen Van Dalen, 'The Fading Public Voice', Journalism Studies, (2012), 1-16. Page. 8-9.

16. Elteren, Americanism and Americanization: A Critical History of Domestic and Global Influence. Page 145-147.

17. Anonymous, 'Nycop Om Pressen Til År 2000, En Udvikling I Tre Trin Med Data, Satelitter Og Video [Nycop About the Press Untill 2000, a Development in Three Steps with Data, Satellites and Video]', Journalisten, /7-8 (August, 1969). 
18. Elteren, Americanism and Americanization: A Critical History of Domestic and Global Influence. Page 145-178.

19. Ibid. Page 145-178.

20. Ibid. Page 145-178.

21. Kurt Boelsgaard, 'Sabbatår Med Ekstra Slid [Sabbatical with Extra Work]', Journalisten, /9 (1970). Page 11.

22. The Danish School of Journalism was established in 1962 but journalists only spent between three and six months there as part of their training. Only in 1970 was the current model of at least two years' education established. Anker Brink Lund and Jørn Henrik Petersen, 'Ny Journalistuddannelse I Danmark', Nordicom-Information, 21/3 (1999), 87-94. Page 87-88.

23. Morten Sabroe, 'Den Litterære Journalistik [the Literary Journalism]', <http://www.update.dk/cfje/VidBase.nsf/ID/VB00139974>, accessed November 4, 2010.

24. John Chr. Jørgensen, Journalistik Med Stil: Fra Klassiske Nyheder Til Fortcelling [Journalism with Style - from Classical News to Narrative] (Aarhus: Ajour, 2007). Page 28. According to Jørgensen, New Journalism in important respects drew from old literary methods, most notably $19^{\text {th }}$ century realism, but it was novel in the United States because it was so markedly different from the descriptive style of the inverted news triangle. In New Journalism the journalist's voice and his or her interpretations of observed events were an integral part of the new technique.

25. Ibid. Page 17-18 and 24-30.

26. Mogens Berendt, 'Den Ny Journalistik [the New Journalism]', Journalisten, /2 (February 1974). Page 22-23. My translation.

27. Gay Talese, 'Joe Louis: The King as a Middle-Aged Man', Esquire, (1962).

28. Jørgensen, Journalistik Med Stil: Fra Klassiske Nyheder Til Fortcelling [Journalism with Style - from Classical News to Narrative]. Page 32. My translation.

29. Ibid. Page 28-33.

30. Ibid.Page 50. My translation.

31. Woodward and Bernstein, All the President's Men. Page 2. My translation.

32. Jørgensen, Journalistik Med Stil: Fra Klassiske Nyheder Til Fortcelling [Journalism with Style - from Classical News to Narrative].

33. Knud Buchardt, 'Journalistik Er at Rejse Ind I En Fremmed by [Journalism Is to Travel into a Unfamiliar City]', Journalisten, (1983). Page 14-15.

34. Mikkel Hvid, Fascinerende Fortcelling [Fascinating Storytelling] (Århus: Ajour, 2002). Page 7.

35. Peck, 'Amerikansk Journalistik [American Journalism]', ( Page 20.

36. Jørgensen, Journalistik Med Stil: Fra Klassiske Nyheder Til Fortcelling [Journalism with Style - from Classical News to Narrative]. Page 27-30.

37. Allern and Blach-Ørsten, 'The News Media as a Political Institution : A Scandinavian Perspective', ( Introduction xiv.

38. Kurt Søndergaard, 'Journalistik Eller Hævntørst? [Journalism or Revengefulness?]', Journalisten, /May (1978). Page 12-16.

39. Ole Schierbeck, 'Rapport Fra En Mudderpøl [Dispatch from a Puddle of Mud]', ibid. (1974). Page 12. My translation.

40. Ibid. Page 12. Incidentally, 1974 was also the year that Berendt introduced Journalisten's readers to New Journalism.

41. Ibid. Page 12.

42. Journalisten, 'Syv Regler for Investigative Reportere [Seven Rules for Investigative Reporters]', ibid. (1978). Page 16.

43. Kurt Søndergaard, 'Journalistik Eller Hævntørst? [Journalism or Revengefulness?]', ibid./May ( Page 12-16. My translation.

44. Woodward and Bernstein, All the President's Men. Page 1.

45. Stig Petersen, 'Kun Få Medier Åbner for Den Dybdeborende Journalistik [Only a Few Media Outlets Open to the in-Depth Journalism]', Journalisten, /February (1982a). Page 23.

46. Stig Petersen, 'Dybdeborende Journalistik Efter Gør-Det-Selv-Princippet [in-Depth Journalism Based on the Do-It-Yourself-Principle]', Journalisten, /June (1982b).

47. Mogens Meilby and Kim Minke, Når Sandheden Skal Frem (Valby: Borgen, 1983).Page 9-15. My translation.

48. Ibid. Page 316-317.

49. Mette Stenumgaard, 'Ny Forening Af Snushaner [New Association for Snoopers]', Journalisten, /January (1990). Page 10-11. My translation.

50. Gregers Dirckinck-Holmfeldt, Tør - Hvor Andre Tier; Vrisne Victor Og Hans Hvalpe [Dares - Where Others Keep Silent; Grumpy Victor and His Pups], 2 vols. (2; Copenhagen: Ekstra Bladets forlag, 2004). 
Page 81-83 and 277. Furthermore, the book describes how Ekstra Bladet developed a successful selfimage of "watchdog" journalism. Additionally, Ekstra Bladet's ability to write from "the bottom up," as former employee described it, as opposed to Politiken's "from the top down" helped create a successful style for the paper.

51. Ibid. Page $82-86$.

52. Stig Petersen, 'Kun Stjerner Graver Dybt [Only Stars Dig Deep]', Journalisten, /March (1982c).

53. For additional discussion of the ethics of Wallraff's method see Christine Isager, 'Skribenter Der Skaber Sig [Writers Who Make a Scene]', (Copenhagen: University of Copenhagen. Department of Media, Cognition and Communication.Section of Rhetoric. , 2006). Page 20-33. See also Investigative Reporters \& Editors' website: (http://www.ire.org/resource-center/. Accessed August 7, 2012).

\section{Bibliography}

Allern, S. \& Blach-Ørsten, M. (2011) 'The News Media as a Political Institution : A Scandinavian perspective', Journalism Studies, 12 (1) 92-105.

Anonymous (1969) 'Nycop om pressen til år 2000, en udvikling i tre trin med data, satellitter og video [Nycop about the Press untill 2000, a Development in Three Steps With Data, Satellites and Video]', Journalisten, (7-8).

Benson, R., et al. (2012) 'Media Systems Online and Off: Comparing the Form of News in the United States, Denmark and France', Journal of Communication, 62 (1) 21-38.

Berendt, M. (1974) 'Den ny journalistik [The New Journalism]', Journalisten, (2).

Boelsgaard, K. (1970) 'Sabbatår med ekstra slid [Sabbatical with Extra Work]', Journalisten, (9).

Buchardt, K. (1983) 'Journalistik er at rejse ind i en fremmed by [Journalism is to Travel into a Unfamiliar City]', Journalisten.

Dirckinck-Holmfeldt, G. (2004) Tør-Hvor andre tier; Vrisne Victor og hans hvalpe [Dares - Where Others Keep Silent; Grumpy Victor and his Pups], 2 vols., 2; Copenhagen: Ekstra Bladets forlag.

Elteren, M.van (2006a) Americanism and Americanization: A Critical History of Domestic and Global Influence. Jefferson, North Carolina: McFarland \& Company, Inc., Publishers.

Elteren, M. van (2006b) 'Rethinking Americanization Abroad: Toward a Critical Alternative to Prevailing Paradigms', The Journal of American Culture, 29 (3).

Halberstam, D. (2000) The Powers That Be. Urbana and Chicago: University of Illinois Press.

Hallin, D.C. (2000) 'Commercialism and Professionalism in the American News Media', in J. Curran \& M. Gurevitch (eds.) Mass Media and Society. 3rd edn.; London: Oxford University Press.

Hallin, D.C. \& Mancini, P. (2004) Comparing Media Systems. Three Models of Media and Politics. Cambridge: Cambridge University Press.

Hallin, D.C. \& Benson, R. (2007) 'How States, Markets and Globalization Shape the News: The French and US National Press, 1965-97', European Journal of Communication, 22 (1) 27-48.

Hamilton, J.T. (2005) 'The Market and the Media', in Geneva Overholser and Kathleen Hall Jamieson (eds.) The Press. Institutions of American Democracy; New York: Oxford University Press.

Hvid, M. (2002) Fascinerende fortcelling [Fascinating Storytelling]. Århus: Ajour.

Isager, C. (2006) 'Skribenter der skaber sig [Writers Who Make a Scene]', Copenhagen: University of Copenhagen. Department of Media, Cognition and Communication.Section of Rhetoric.

Journalisten (1978) 'Syv regler for Investigative reportere [Seven Rules For Investigative Reporters]', Journalisten.

Jørgensen, J.C.(2007) Journalistik med stil: Fra klassiske nyheder til fortcelling [Journalism with Style - From Classical News to Narrative]. Aarhus: Ajour.

Lund, A.B. \& Petersen, J.H. (1999) 'Ny journalistuddannelse i Danmark', Nordicom-Information, 21 (3) 87-94.

Meilby, M. \& Minke, K. (1983) Når sandheden skal frem. Valby: Borgen.

Peck, H.T. (1906) 'Amerikansk journalistik [American Journalism]', Journalisten, October 1.

Petersen, S. (1982a) 'Kun Få Medier Åbner for Den Dybdeborende Journalistik [Only a Few Media Outlets Open to The in-Depth Journalism]', Journalisten, (February).

Petersen, S. (1982b) 'Dybdeborende journalistik efter gør-det-selv-princippet [In-depth Journalism Based on the Do-It-Yourself-Principle]', Journalisten, (June).

Petersen, S. (1982c) 'Kun stjerner graver dybt [Only Stars Dig Deep]', Journalisten, (March).

Sabroe, M. (2010) 'Den litterære journalistik [The Literary Journalism]', http://www.update.dk/cfje/VidBase. nsf/ID/VB00139974, accessed November 4,

Schierbeck, O. (1974) 'Rapport fra en mudderpøl [Dispatch from a Puddle of Mud]', Journalisten.

Skovsgaard, M. \& van Dalen, A. (2012) 'The Fading Public Voice', Journalism Studies, 1-16.

Stenumgaard, M. (1990) 'Ny forening af snushaner [New Association for Snoopers]', Journalisten, (January). 
Strömbäck, J. \& Dimitrova, D.V. (2006) 'Political and Media Systems Matter: A Comparison of Election

News Coverage in Sweden and the United States', Press/Politics, 11 (4) 131-47.

Søndergaard, K. (1978) 'Journalistik eller hævntørst? [Journalism or Revengefulness?]', Journalisten, (May).

Sørensen, N.A. (2009) 'Kulturmøder, selvkolonisering og imperialisme Om USAmerikaniseringen af Europa

[Cultural Encounters, Self-Colonialization and Imperialism: About USAmericanization of Europe]', in A.

Magnussen, S. Bjerrum Fossat, K. Petersen, N.A. Sørensen, (ed.) Transnationale historier [Transnational Histories] Odense: Syddansk Universitetsforlag.

Talese, G. (1962) 'Joe Louis: The King as a Middle-Aged Man', Esquire.

Wolfe, T. (1996) The New Journalism: With an Anthology edited by Tom Wolfe and E. W. Johnson. London: Picador.

Woodward, B. \& Bernstein, C. (2005) All the President's Men. Paperback edn.; New York: Pocket Books.

ANDERS BO RASMUSSEN, Ph.D., Assistant Professor, Center for American Studies, University of Southern Denmark, ras@sdu.dk 